\title{
Skaplonking: Neologism and Euphemism for Plagiarism
}

\author{
Jaime A. Teixeira da Silva \\ P. O. Box 7, Miki-cho post office, Ikenobe 3011-2, Kagawa-ken, 761-0799, Japan \\ jaimetex@yahoo.com
}

\section{Doi:10.5901/jesr.2015.v5n2p13}

Plagiarism and self-plagiarism have taken center stage of the misconduct play globally as authors, editors and publishers seek ways in which to effectively deal with the inappropriate use of factual sources. The topic is increasingly hotly debated, and publications related to it are on the rise, as evidenced by the number of publications in the mainstream literature. A crude search using the keyword "plagiarism", which would also encompass self-plagiarism in the search, in some of the mainstream science, technology and medicine (STM) publishers as well as data-bases and search engines reveals some voluminous numbers, and even some surprisingly low numbers (Table 1). Retractions are on the rise because of plagiarism and self-plagiarism, and one of the parties that appears to be benefitting are software companies that have created tools to detect such cases. In many cases, journals have only now, or in the recent past, started to implement systematic plagiarism detection, but are failing to apply equally systematic analysis of the past published literature. For ample reasons that lie beyond the scope of this short paper, plagiarism and self-plagiarism will most likely continue to exist indefinitely, provided that science publishing exists.

The terms plagiarism and self-plagiarism carry negative connotations, evidently, and are usually built into the ethics framework of journals and publishers. However, it is extremely rare (e.g. [1]) to see retraction notices that blatantly label similar text as plagiarism or self-plagiarism. In most cases, editors and most likely the legal teams of publishers will avoid using such pointed language, most likely also to avoid legal challenges by authors, or their institutes. Thus, one tends to find a host of euphemistic language in retraction notices that tends to dilute or diffuse the seriousness of plagiarism and self-plagiarism.

Given the increasing legal risk of using these two terms, and the moral and ethical implications that are associated with them, especially when scientists refer to each other's work, I have coined a new English neologism, to describe the use of ideas, text or any form of intellect, without due attribution: "skaplonking". Since the word itself does not exist in any English dictionary, nor can any similar words be identified in any data-base or even on Google or similar web search engines, it seems to be an excellent neologism to describe plagiarism. By using this neologism, authors could hypothetically defend themselves against libel because they are using a term that in fact does not officially exist, in any language. Thus, theoretically, one cannot be charged with claiming something that does not exist. This neologism thus serves as an intellectual academic buffer. This short note describes the different forms in which this word could be used. Throughout, plagiarism and self-plagiarism will be represented by $X$ and self- $X$, respectively, where $X$ represents the base skaplonking.

Noun: skaplonk; self-skaplonk;

Verb: to skaplonk; to self-skaplonk;

Adjective: skaplonky or skaplonktious; self-skaplonky or self-skaplonktious;

Adverb: skaplonktiously; self-skaplonktiously.

This neologism could also be used in some other languages, for example Spanish or Portuguese:

Noun: escaplonque; auto-escaplonque;

Verb: escaplonquear (thanks to Toby on [1]); auto-escaplonquear;

Adjective: escaplonqueoso; auto-escaplonqueoso;

Adverb: escaplonqueamente; auto-escaplonqueamente.

Or in Japanese:

Noun: スカプロンコ (pronounced su-ka-pu-ro-n-ko);

Verb: スカプロンコをする(pronounced su-ka-pu-ro-n-ko o suru).

As I discuss anonymously in [1], one important application of this neologism, is in self-skaplonking. How much skaplonking of one's own words, ideas, data, or figures, is deemed to be ethically acceptable? Consequently, we need a set of skaplonking guidelines that clearly define the percentage of skaplonking that is acceptable. In order to enforce and 
disseminate skaplonking, an anonymous Committee of Skaplonking, or COS, could be formed, not unlike the Committee on Publication Ethics (COPE), in terms of its noble objectives.

In order to detect skaplonking and self-skaplonking, software would be useful and I propose a new product name: TurnipSkaplonk, so as not to be confused with the now popular, non-free Tunitln ${ }^{\circledR}$ software by iParadigms. The wider scientific community should make TurnipSkaplonk open free-ware, thus benefitting science and not business. And, to more easily allow for the wider acceptance of this euphemistic neologism, a Creative Commons Attribution (CC BY) license would allow the use of the term skaplonk and all of its derivative forms, provided that the original source is fully referenced, namely this paper and the comment section at [1]. Finally, the sleuths who are working hard to detect cases of skaplonking are encouraged to use this new term. The STM publishers, including their editors and journals, have the responsibility of scanning all papers in their repositories for cases of skaplonking or self-skaplonking. There would be no costs of completing this arduous task by free-ware TurnipSkaplonk in which a report could be generated in real time, online. IT specialists are urged to rapidly develop TurnipSkaplonk, thus removing all costs to authors, and boldly reinforcing publishing ethics.

My critics would claim that adding the term "skaplonking" to an already noisy publishing landscape would serve no new purpose. I would disagree. It would provide one more tool with which scientists could defend the validity of their statements and claims, potentially buffering from negative associations associated with the use of the term "plagiarism", or its derivatives.

\section{Conflict of Interest Statement and Disclaimer}

The author declares that the research for this paper was conducted in the absence of any commercial, financial or other relationships that could be construed as a potential conflict of interest. The author declares that he is the anonymous poster "Skaplonking = "P"' in the comments section of [1].

\section{References}

[1] http://retractionwatch.com/2015/02/04/unacceptable-level-text-parallels-loses-neuroscientist-paper-not-phd/

Table 1. Ranking of hits in a crude search for the term "plagiarism" on the search function of different data-bases and STM publisher web-sites.

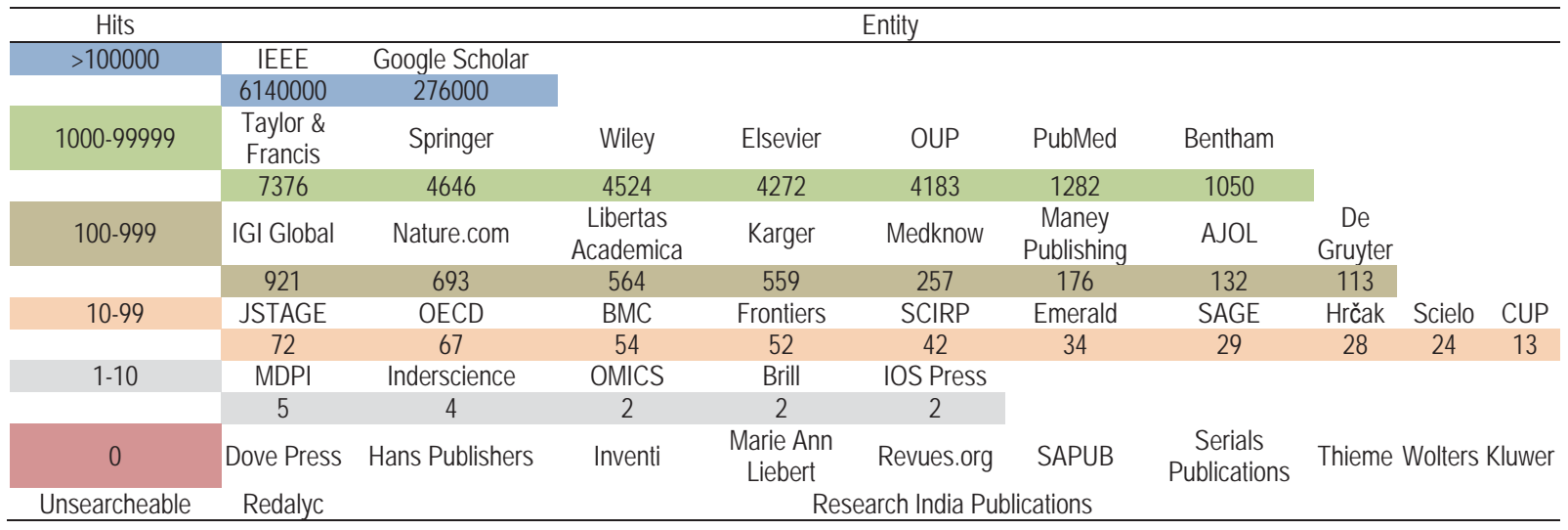

